\title{
INFRASTRUCTURE ASSESSMENT FOR DEVELOPING ROUTE EVACUATION OF BENGAWAN SOLO RIVER FLOOD AT BOJONEGORO DISTRICT
}

\author{
Zharin F. Syahdinar and Umboro Lasminto \\ Post Graduate Student of Civil Engineering ITS and Lecture of Civil Engineering ITS, Sukolilo, Surabaya, Indonesia \\ E-mail: zharinfsyahdinar@gmail.com, umboro.lasminto@gmail.com
}

\begin{abstract}
.
Bengawan Solo River is the biggest watersheet in java, Indonesia. It is reach between two provinces, Central Java and East Java. The flood's happens almost every year on this river. The floods caused by increased rainfall on rainy season, and land use in upstream has changed too. The community not want to abandon their land so, they must living and adaptable with disaster. Beside that, decrease of river's flow capacity and catchment area are the significant factor of causing floods in Bengawan Solo river. The villages nearest with river get susceptible floods area. In Bojonegoro district there was 23 of flooded sub-district. Using supported information and map of road network, topography, provisional care, and infrastructure condition. Then assessment of infrastructure damaged such as roads, bridges, railway, etc. from that information and assessment, capable to created evacuated lines map for flood's victim in Bojonegoro district using GIS. This map can useful as a guide the victim to safety line and nearest provisional care when flood disaster has come out .
\end{abstract}

keywords : Assessment, Bengawan Solo River, Bojonegoro, Flood, Disaster, Evacuated route Maps, GIS

\section{INTRODUCTION}

Bengawan Solo watershed is the greatest watershed in Java and located between Central Java and East Java province. Its width is around 1.594.716.22 hectare. This location is located at $110018^{`} E a s t$ longitude to $112045^{` E}$ East longitude. This watershed consists of 17 districts and 3 cities. The districts are Boyolali, Klaten, Sukoharjo, Wonogiri, Karanganyar, Sragen, Blora, Rembang, Ponorogo, Pacitan, Madiun, Magetan, Ngawi, Bojonegoro, Tuban, Lamongan, Gresik .

Several solutions had been conducted by government in order to handle the flood issue such as build a rumen and dam for retain the remnant water in Bengawan Solo watershed. The problem is the rate of Bengawan Solo river flow that always comes every year with high puddle and always changes around $3,000 \mathrm{~m}^{3} / \mathrm{s}$ during rainy season. This can cause the flooded area to be widen even more. Bojonegoro is district that always had big flood area. This caused by bojonegoro district is the biggest district in East Java and the minimum sloop topography. In addition to Bengawan Solo river flow there is community of the land can't be moved out or abandon their home. Accordingly the situation, every year they must living with disaster and going to evacuated place. The route have more safety issues because they just use inform in annual condition.

Assessment method that is used is only to evaluate assumption assessment and properness of evacuation tracts infrastructure and seeking for the closest evacuation track. After that the other solution to face this flood issue will always be searched.

\subsection{THE PROBLEMS}

Based on the background about the flood in bengawan solo watershed above, which

a) How is the condition and what are the causes of the flood in Bengawan Solo river?

b) How is the condition of the infrastructure for evacuation track after the flood? c) How to inform the evacuation route in Bojonegoro district?

\subsection{THE GOALS}

From the assessment that had been done, the goals are

a) Find out the condition and the causes of Bengawan Solo river flood.

b) Find out the condition of the infrastructure for evacuation route while the flood.

c) Mapping the flooded area and evacuation route in Bojonegoro District.

\subsection{BOUNDARY CONDITION}

In this research, have boundary condition where

a) Research area consists of bengawan solo watershed that flows in bojonegoro, tuban, and lamongan district

b) Not observing the social effect of the flood in detail

c) Not observing the material loss of the flood in detail

d) Not doing the Direct measurement about the height of the flooded area

e) The flooded area map is made based on the data record of the flooded area.

\section{LITERATURE REVIEW}

2.1 Hazards and Disaster

There have a two types of hazards are natural and human-made hazard. Natural hazards are the hazards which affected by environment condition; human-made hazards are those arise by human activities. The natural disaster capable described scholarly as misnomer and confuse definition probably. The differences between natural hazard and disaster are natural hazards can be environment events, meanwhile disaster is the compilation of hazard and the existing human vulnerabilities. There's hard to avoid the natural hazard and this cause became a natural disaster the natural hazard such as floods, hurricanes, volcanic, tsunami, and wildfires. ${ }^{1)}$ (adelman and Gray, 2008) 
In another hand, hazard definition is something causing disaster, It is caused by human activity or nature, give impact to human activity, property and life ${ }^{8)}$ (Oscar, 2011). Hazards is activity or events have potential damage and became a disaster if effected human life. Hazard attached by some factors to became a disaster although, hazard was the problem. The terminology and difference between hazard and disaster explained in diagram 1 .

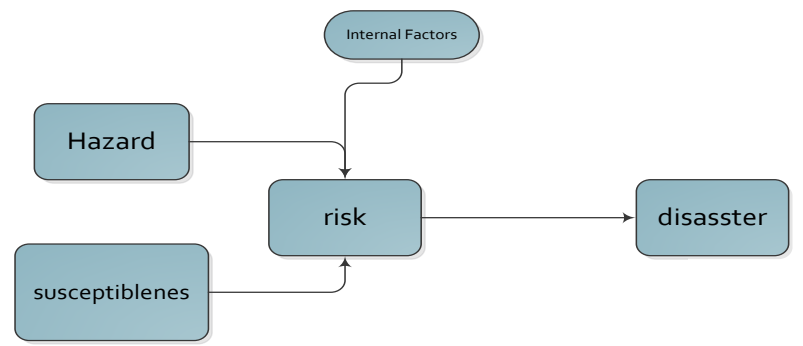

Diagram 1. Terminology of hazards and disaster 2.2 Flood

Flood is land full covering by water, where usually is dry, caused by over flow in river on rainy season and made disadvantage to community in material or immaterial. Floods happened every year depends on the river cross the land and the peak season on rainfall. The land have covering by water is called flooded area. In any case, there have more than two flooded area with different level of water, caused by one river.6) (Siswoko on Indradewa, 2008).

Floods are a normal circumstance in many parts of worlds. It is being a part of ecological and agricultural system because floods capable to regenerating of land, aquatic component, and any livelihoods derived from them. 14) (Wisner and friends, 2004). Accordingly that, rivers allow to their natural flow transform it. Paradoxically, floods made an affect the areas time by time, this phenomenon happened in Bengawan Solo stream and the flood.

\subsection{Assessment.}

Accordingly $\mathrm{UNDP}^{16)}$, risk have definition as the probability of harmful consequences by resulting from interaction natural or human induced hazard and vulnerable condition. In this case risk assessment is not only evaluated the important and probability of potency losses but also showed to improve knowledge the caused and effect of the disaster. ${ }^{16)}$ (UNDP, 2010)

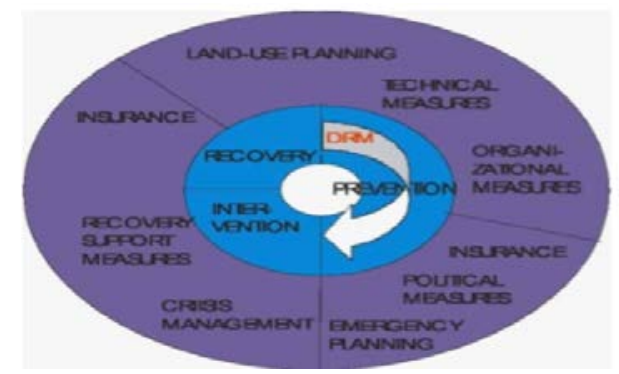

Figure 1. Risk management and mitigation cycle (Bierri on Direktorat Pengairan dan Irigasi, 2014)

Assessment is continuity identification data and integrated estimation to act an intervention, purposed to get full information. In assessment its prejudice step by step in disaster cycle, such as: preparedness phase, emergency phase and recovery phase. In each phase, assessment can be handled more than once in the different step. To manage all essential information. ${ }^{4)}$ (Febriyanti, 2010).

\subsection{Geography Information System (GIS)}

Geography Information System (GIS) is a program system to save, recall and analysis spatial data). This program capable to set coordinate of map then give the information easier, particularly for area, roads, rail roads and anything to create maps information. It is capable to build information in a map, then recall the information as well as what the needed. (Forest Watch, 2010)

For example, inform the rivers from main rivers until the little of members rivers use different imaging, the flooded area which the main unsafe area until the affected area with different colours, rail roads and main road with different line.

\subsection{Map of disaster}

Build upon types of hazards and disaster, map of disaster and menace disaster created basic on area disaster happened equal to the frequency and the intensity. Map of hazard and disaster is imaging of level disaster risk in one area from spatial and non-spatial based on study of risk disaster in whole area. ${ }^{2)}$ (Chief Regulation of BNPB no.02/2012)

\section{MATERIAL AND METHODS}

\subsection{Assessment Infrastructure for Evacuated Route}

All of The data about flood histories in Bengawan Solo every year since 2008 until 2013 were obtained from East Java ministry of water resource and from Badan Penanggulangan Bencana Daerah ${ }^{7)}$ (BPBD/ regional Disaster Management Agency) East Java. The recapitulation summary of those data is done based on districts and the dates. Thus the detail information of each flood incident from dates, overflowing rivers, until the effects that happened in the districts which be passed by Bengawan Solo’s stream.

Table 1. Prejudice criteria of transportation infrastruktur (Dirjen Cipta Karya, PU Government Agency, 2014) ${ }^{3)}$

\begin{tabular}{llll}
\hline No & Parameters & Impact & Score \\
\hline \hline $\mathbf{1 .}$ & $\begin{array}{l}\text { Flood happened in congested } \\
\text { transportation area }\end{array}$ & High & 100 \\
\hline \hline $\mathbf{2 .}$ & $\begin{array}{l}\text { Flood happened in average } \\
\text { transportation area }\end{array}$ & Medium & 75 \\
\hline \hline $\mathbf{3 .}$ & $\begin{array}{l}\text { Flood happened in restricted } \\
\text { transportation area }\end{array}$ & low & 30 \\
\hline \hline $\mathbf{4}$ & No road & $\begin{array}{l}\text { Very } \\
\text { low }\end{array}$ & 0 \\
\hline
\end{tabular}

According those data, the maps of flooded area, assessment infrastructure which safety and usually damaged, and maps of evacuated route can be created. The analysis of assessment using manual standard from PU agency (Pekerjaan Umum/ government agency work field in development area). It is show in table 1 bellow. After got the scores of every single affected district and the condition of bridges road and everything about the infrastructure then the safety route has selected. The process of made flooded area and evacuated route using GIS (geography Information System), the cycle describe on diagram 2. 
The floods not just caused infrastructure for roads, its ocurred for loding losses and econoc losses. The method of these assesment had same way with roads infrastructure prejudice, the number of damaged realize in same score criterea were verry low, low, medium and high.

\subsection{Created a map of Flooded Areas And Evacuated Route}

In this research utilize GIS to explain all flooded area and the potential submerged area with the possibilities river produce inudation. Subsequent to those information, the route of evacuated be made. All of the process were observed on diagram 2. Created Flooded Areas and evacuated route Map bellow.

Diagram 2. Created Flooded Areas and evacuated route Maps

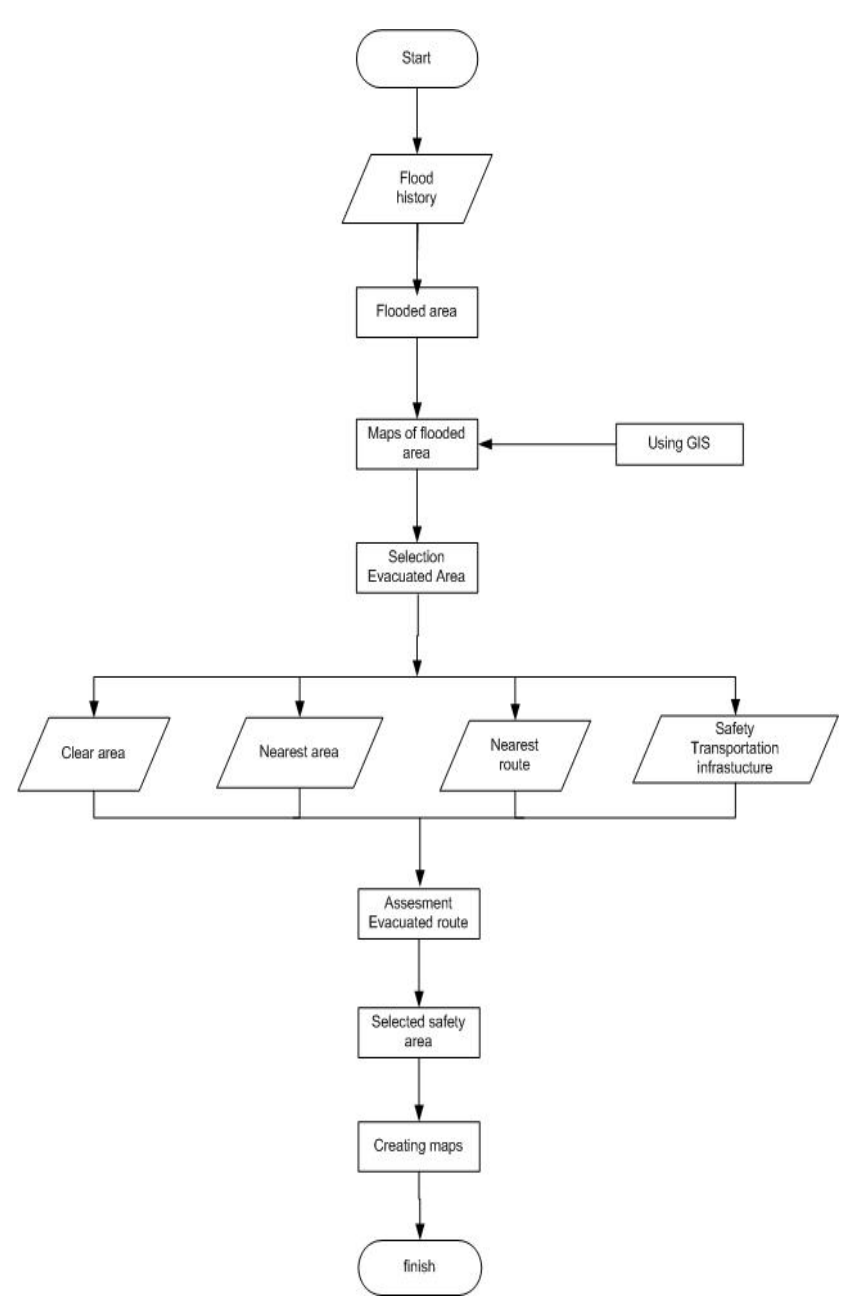

\section{RESULT AND DISCUSSION}

\subsection{The Flood's Factors}

Based on the rainfall data, taken by BMKG, describe in figure 1 , and the events of flooding represented on figure 2 , gave the impact that rainfall be the first factors of the overflow iin Bengawan Solo River.

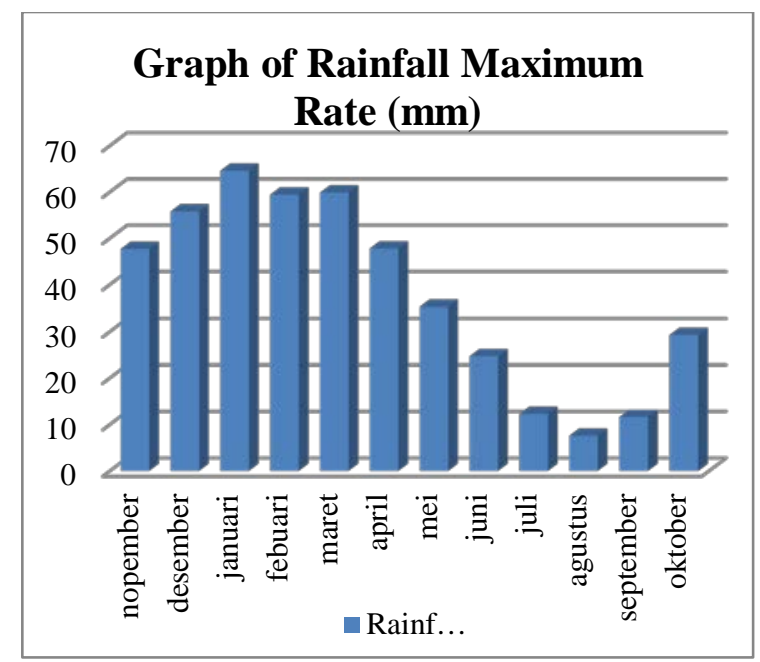

Figure 2. Graph Of Value Rainfall Maximum Rate

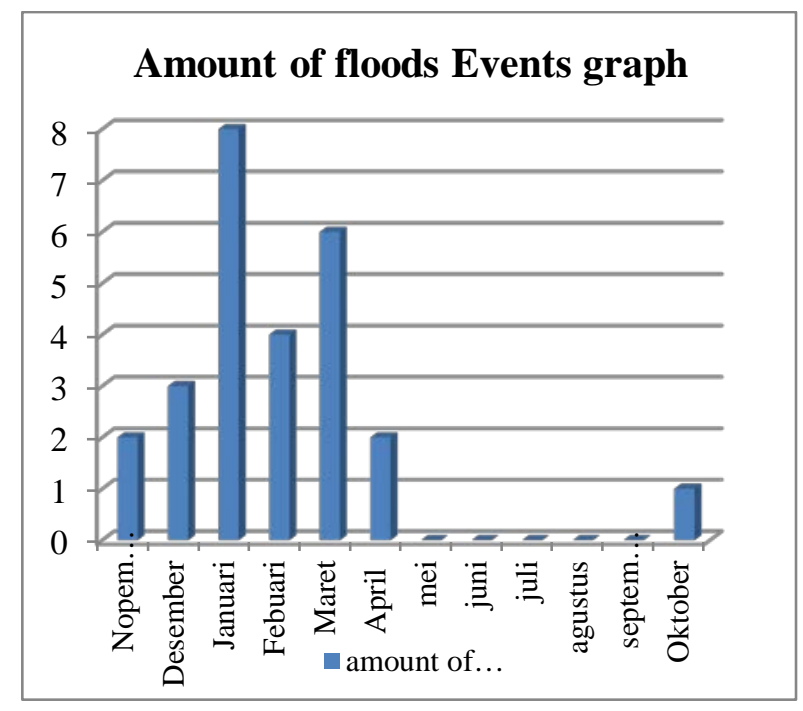

Figure 3. The Graph. Amount of flood Events

The Figure 2 above prescribe maximum rate of rainfall in 1991 until 2005 based BMKG*) (climatology management agency) reported. The next is Figure 3, inform by BPBD about amount of flood events

The relation of those graphs describe that flood is caused by heavy rainfall. The phenomenal explained from chart 1 above, stream of rainfall around $65 \mathrm{~mm}$ on January was coherence with amount of floods event go rise on January. as knowing in opening, this heavy rainfall affected to member of bengawan solo river stream, overflow on the lands and make broken down some facilities. In addition of raindrop and total of occurrence held in same month, which the peak season have much incident than the limited raindrop seasons.

Beside the rainfall, the other factors caused submerged area are the dyke of river damaged, great river sedimentation, and the landscape of Bojonegoro Region was flat around 4 sealevel.

\subsection{The Affected Population}

Total affected population based on report of BPBD east Java in contingencies report at $2014{ }^{7)}$, around 202.821 peoples, total of evacuate population because the level of water amount 2,000 persons which 53,342 are 
children and teenagers, 133,659 adults, and 15,802 are aged.

\subsection{Infrastructure}

Overflow from Bengawan Solo River probably affected public facilities and infrastructure at the flood areas. Generally, public facilities in the flooded area were disconnection, began from network telecommunication, electricity and petrol providers. At the same time, the infrastructure got disconnect too, It is showed on table 2 . Roads submersed of Bengawan solo's flood.

Table 2. Roads submersed of Bengawan solo's flood (analysis data, 2015)

\begin{tabular}{|c|l|l|}
\hline Number & Roads Type & Length (km) \\
\hline \hline 1. & Main road & 0 \\
\hline 2. & Rail roads & 24.39 \\
\hline 3. & Collecting roads & 33.44 \\
\hline 4. & Another roads & 350.55 \\
\hline 5. & Local roads & 65.25 \\
\hline \hline 6. & Lori roads & 5.34 \\
\hline \hline 7. & Footpath & 72.91 \\
\hline \hline. & National tol & 0 \\
\hline \hline 9. & Bridges & 16.04 \\
\hline 10. & Fly bridge & 0.18 \\
\hline \hline 11. & Tunnel & 0.06 \\
\hline \hline 12. & Footbridge & 0.1 \\
\hline 13. & Total & $\mathbf{4 4 0 . 2 6}$ \\
\hline
\end{tabular}

The floods valuation came on with criteria level of water around $20 \mathrm{~cm}-50 \mathrm{~cm}$, it's made score 35 and include low effect. Some of flooded area give score 75 and the transportation such as: roads and rail roads submerged and no accesses to go anywhere when flooding it's give score 100 prefer to evacuated chosen location by BPBD East Java, then build on safety evacuate route which are worthwhile every flood happens. The width estimation considerable flooded area in Bojonegoro District inform on table 3 bellow. With the result that calculated of places nearby and safe area for evacuated place and the way to get there with evacuated route.

Table. 3 Estimation Considerable Flooded Area Every Year (BPBD East Java, 2015) ${ }^{7)}$

\begin{tabular}{|lll|}
\hline NO. & District & $\begin{array}{l}\text { Width } \\
\text { (Hektar) }\end{array}$ \\
\hline BOJONEGORO & $\mathbf{1 7 5 2 9 . 0 7}$ \\
\hline $\mathbf{1}$ & BALEN & 1642.79 \\
\hline $\mathbf{2}$ & BAURENO & 2197.03 \\
\hline $\mathbf{3}$ & BOJONEGORO & 1019.48 \\
\hline $\mathbf{4}$ & DANDER & 782.06 \\
\hline $\mathbf{5}$ & KALITIDU & 2487.72 \\
\hline $\mathbf{6}$ & KANOR & 960.13 \\
\hline $\mathbf{7}$ & KAPAS & 449.26 \\
\hline $\mathbf{8}$ & KASIMAN & 939.24 \\
\hline $\mathbf{9}$ & MALO & 3236.27 \\
\hline $\mathbf{1 0}$ & MARGOMULYO & 270.33 \\
\hline $\mathbf{1 1}$ & NGRAHO & 223.48 \\
\hline $\mathbf{1 2}$ & PADANGAN & 1454.46 \\
\hline $\mathbf{1 3}$ & SUMBEREJO & 147.15 \\
\hline $\mathbf{1 4}$ & TRUCUK & 1719.67 \\
\hline
\end{tabular}

The infrastructure losses not just from submerged roads, but it was included losses for civilian habitation, splurge economic income after disaster for evaluation of criteria had same way with table 1 , used parameter very low, low, medium and high.

As a results of assessment by floods histories from 2008 to 2013.mesurement with summarize all aspect found that Bojonegoro had high rate became risk land of Bngawan Solo river's Flood. As a reason this paper help to made a new evacuated route utilize map and some information of many times disconnected dyke, rail roads, village roads when overflow happened.

Detail of safety track will be explained in evacuated route session, in this paper include the map track and the safe place to stay during the floods happened.

\subsection{Evacuated Route and Located}

Almost floods happened every year in Bojonegoro district. Accordingly those situations, some evacuate area located in some point on safe are. But in case, some people choose to live in their home with reason the level of water around $20 \mathrm{~cm}-50 \mathrm{~cm}$, the estimation of areas width covered by water indicated on table 3 .

Safe area chosen by dried area where in outside of impact areas, provided clean water and electricity, then have good accessibility in telecommunication and transport. Based on regulation of BNPB (National agency of hazard and disaster) no. 7, 2008, ${ }^{8)}$ selected the point/ evacuate place on government and social building as evacuate. The information of amount the building and the capacity showed in table 4 . About the recommendation places of building as evacuate place be conceived on figure 4.

Table 4. Requirement Temporary Evacuate Places (TEP)

\begin{tabular}{|c|c|c|c|}
\hline NO. & KECAMATAN & $\begin{array}{l}\text { Evacuated } \\
\text { place }\end{array}$ & $\begin{array}{l}\text { Capacity } \\
\text { (person) }\end{array}$ \\
\hline 1 & BALEN & 1 & \pm 200 \\
\hline 2 & BAURENO & 2 & \pm 200 \\
\hline 3 & DANDER & 1 & \pm 100 \\
\hline 4 & KALITIDU & 4 & \pm 300 \\
\hline 5 & KANOR & 1 & \pm 100 \\
\hline 6 & KAPAS & 1 & \pm 100 \\
\hline 7 & KASIMAN & 1 & \pm 100 \\
\hline 8 & MALO & 2 & \pm 200 \\
\hline 9 & MARGOMULYO & 1 & \pm 50 \\
\hline 10 & NGRAHO & 2 & \pm 200 \\
\hline 11 & PADANGAN & 2 & \pm 200 \\
\hline 12 & SUMBEREJO & 1 & \pm 50 \\
\hline 13 & TRUCUK & 3 & \pm 600 \\
\hline$\overline{\text { TOT }}$ & & 21 & \pm 2.4000 \\
\hline
\end{tabular}

The detail information about flood history and the affected specifically for infrastructure from Water Resource Department and BPBD East Java, describe on figure 5. The data collected from 2009 until 2013, then classified by sub-district, village, date, and river. Flick trough introduction, that the causes of floods by only main river, is Bengawan Solo, but this causing by the member 
of group Bengawan solo water sheet. The recapitulation of information, made easier to evaluated caused and the damaged of infrastructure. After that using method assessment on table 1, inform that Bengawan Solo river and Pacal river were the most avoiding river, the information of assessment score on table 5. According that assessment the roads cross that river unsafe to be evacuated routes, beside that on that rivers needed maintenance every year or maybe build the better roads/bridge which adaptable with river stream.

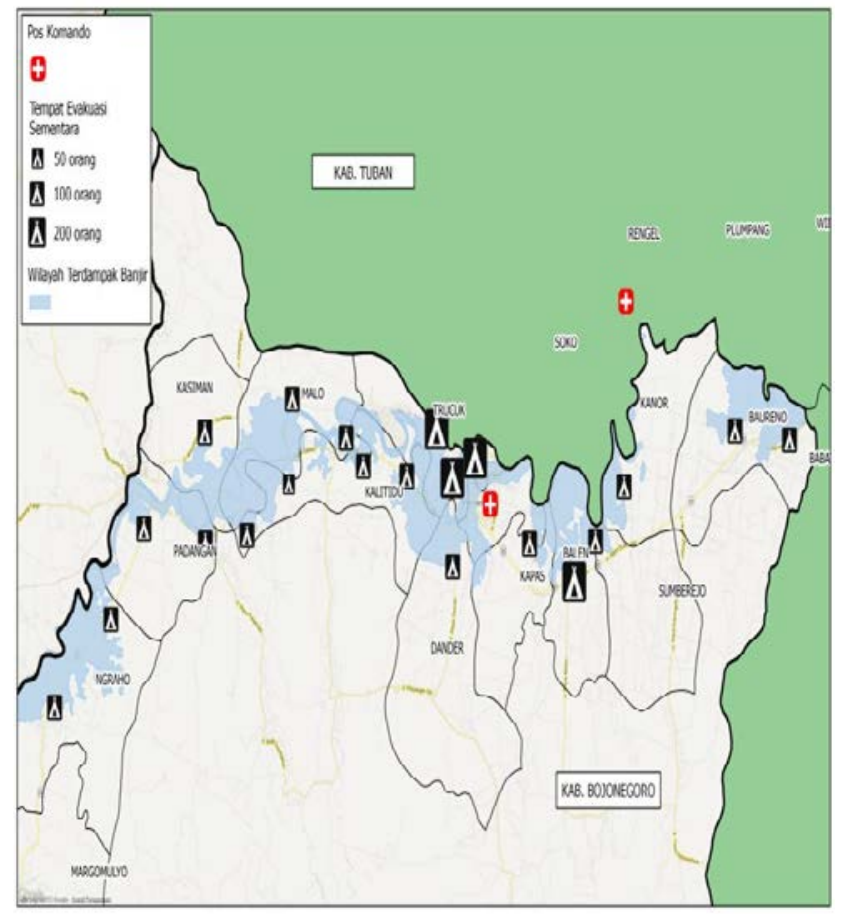

Figure 4. Recommendation Places Of Building Evacuate Place (BPBD East Java, 2014) ${ }^{7)}$

\subsection{The Infrastructure Assessment.}

By information of Bengawan Solo river floods from 2008 until 2013 and used Table1. Prejudice criteria of transportation infrastructure, gave the result of assessment score for this section maximal are in 100 it is gave high affect from disaster. According that, it was conducted to rebuild new infrastructure. The result showed in figure 5 bellow

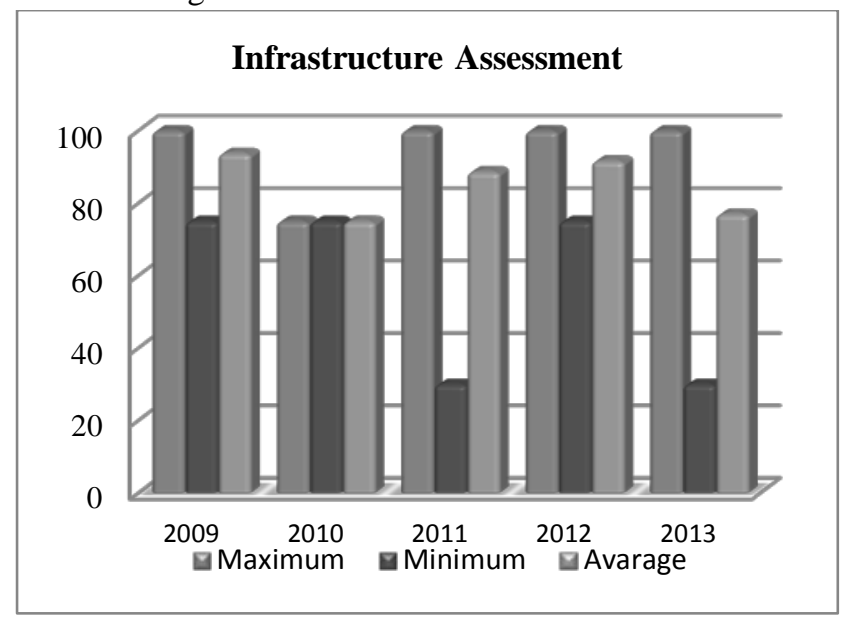

Figure5. Graph of Infrastructure Assessment

For infrastructure area, result of average just around 30 until 75, it was caused by the infrastructure in Bojonegoro were almost a village roads. Because that, it was not give much influence result for the prejudice based on urban city.

However, the floods in reality gave negative affect for the community in their activities. Most of them were a farmer, land worker, and fish farmers. Consequence of calamity was homeless, so they must move to evacuated place and made safety life follow the safety roads. The assessment of year just showed in 2008 and 2009, imagery on figure 5 there in after. The assessment had four different criteria, which are: infrastructure (for roads), flooded area, economic, and lodging. The estimated based on floods histories and the point score of classes assessment. Each part had standard, 100 for high effect and 30 for low effect.

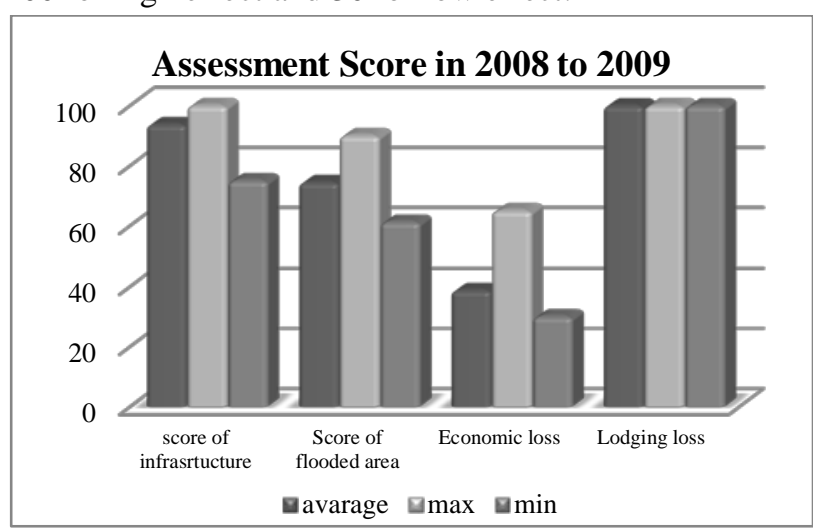

Figure 5. Assessment Score in 2008 to 2009

From the assessment each year, capable to make an averaged summarize for general. The score of each year had to average by the standard. The maximal approximately must 100 point. As a result of the average summarize assessment score showed in figure 6 . The result showed that lodging loss became the highest score. It was caused the area studied was a settlement area. In contrast, economic got the lowest. This was caused Bojonegoro district was not industry areas.and the assessment for economic in Indonesia just explain about industrial not mention about losses of farming and agriculture.

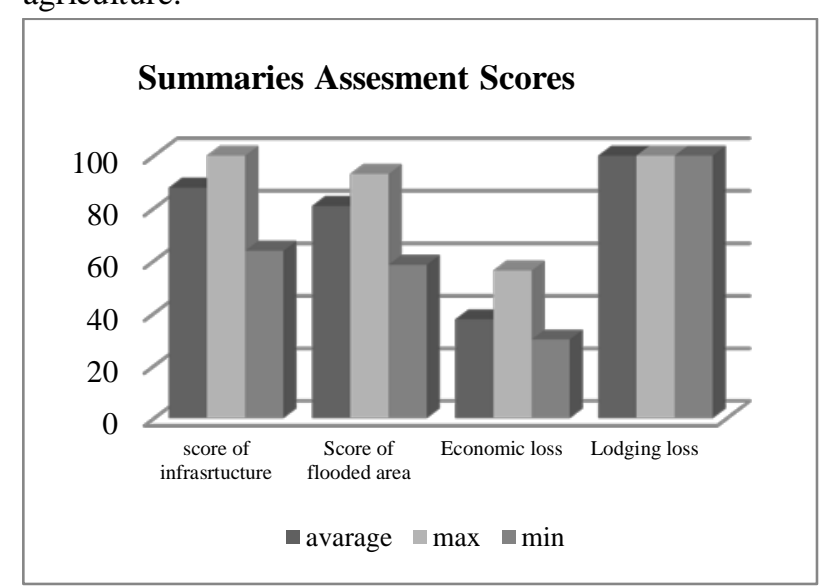

Figure. 6. Summarize Assessment Score.

Subsequently, the assessment had to summarize and give the result as assessment of flood's score. Overall the peak must 400 point. In case, there had four criteria of assessment with the maximal score was 100 . The calculated based on policy of Government Agency, 2014 ${ }^{3)}$. For the result illustrate by figure 7 Assesment of Flood's Score 


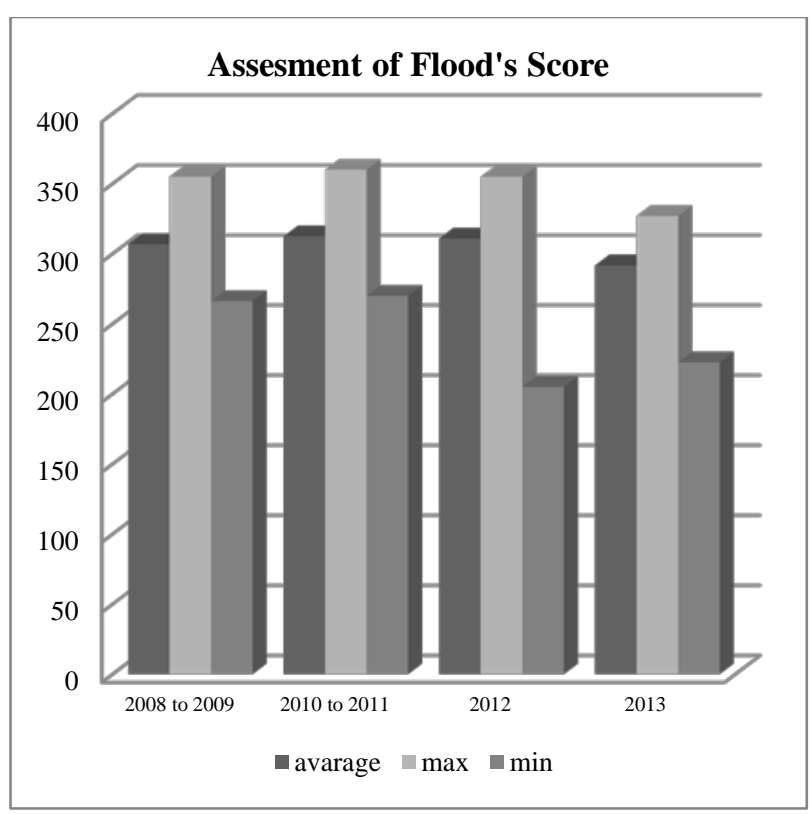

Figure 7 Assesment of Flood's Score.

Similar in procedure of each criteria the total result in every year be calculated until got the averaged point. Therefore, the maximal estimation score was 349.25 point to 400. It was indicated that the floods became a disaster an high negative effort, on figure 8. From those chart figured the assessment score of flooded effect, by flooded area, economic, and lodging. Every year have enlarged submerged area. The score had summary in this figure 8

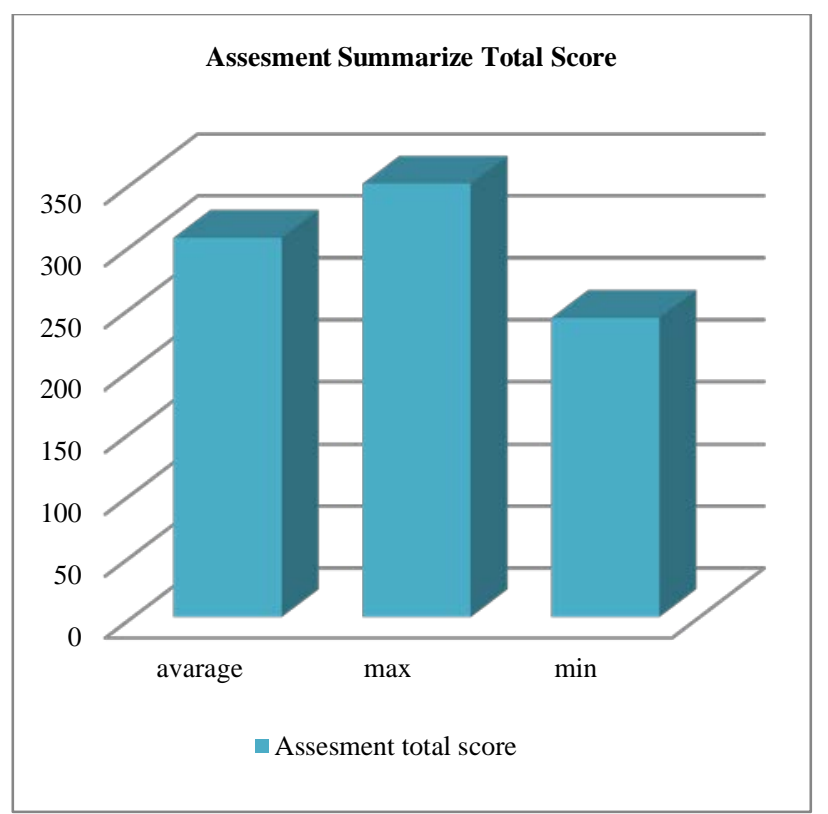

Figure 8. the Assessment Summarize Total Score

There were need some criteria to made sum assessment of the infrastructure and make sure to got safe place, these indicated that infrastructure could be damaged. And one characteristic could be insert is the possibility of the river became a factor of damaged beside the rainfall. After look at the information of flooded area, the safety route for evacuated could be illustrate. The point should be note is do not use route near the river.

The assessment score for risk river infort on table 5 afterwards.

Table 5. Assesment scores from Information about flood history and the affected specifically for infrastructure ${ }^{9,10,11,12,13,14)}$

\begin{tabular}{|c|c|c|c|}
\hline River & $\begin{array}{l}\text { score } \\
\text { s }\end{array}$ & Damaged & Impact Sub-district \\
\hline Pacal & 100 & $\begin{array}{l}\text { Village bridge lost and flooded area especially village } \\
\text { roads. } \\
\text { flooded area on } 4 \text { sub-district }\end{array}$ & $\begin{array}{l}\text { Temayang, Kapas, Balen and } \\
\text { Sukosewo. }\end{array}$ \\
\hline $\begin{array}{l}\text { Bengawan } \\
\text { Solo }\end{array}$ & 100 & $\begin{array}{l}\text { Village roads/ local roads damaged and some dyke broken- } \\
\text { down } \\
\text { Impair rail roads in bojonegoro } \\
\text { Flooded area in } 15 \text { district }\end{array}$ & $\begin{array}{l}\text { Margomulyo, Padangan, } \\
\text { Purwosari, ngraho, Kasiman, } \\
\text { Gayam, Kalitidu, Malo, Trucuk, } \\
\text { Dandar, } \\
\text { Bojonegoro, Kapas, Balen, } \\
\text { Kanor and Baureno }\end{array}$ \\
\hline Merukis & 75 & $\begin{array}{l}\text { Main village roads and province road were flooded and } \\
\text { made lost connections between } 2 \text { district and region. Some } \\
\text { bridges were damaged. } \\
\text { Flood are on } 1 \text { districts }\end{array}$ & kanor \\
\hline $\begin{array}{l}\text { Pundung } \\
\text { Kembar } \\
\text { Afvour }\end{array}$ & 75 & Province roads are flooded. & Baureno and Balen \\
\hline $\begin{array}{l}\text { Semarmende } \\
\text { m, Brangkal, } \\
\text { and kerjo }\end{array}$ & 75 & $\begin{array}{l}\text { Village roads and PU roads were flooded. } \\
\text { Flooded areas were reach } 2 \text { district. }\end{array}$ & Kepohbaru and Baureno \\
\hline $\begin{array}{l}\text { Pohwates } \\
\text { Afvaor }\end{array}$ & 75 & PU roads flooded & Kepuhbaru \\
\hline Loro & 30 & Main village roads were flooded & Bojonegoro and kapas \\
\hline Soko & 30 & $\begin{array}{l}\text { A Bridge broken and made flood village roads. Flooded } \\
\text { area on } 2 \text { districts. }\end{array}$ & Temayang and Dandar \\
\hline $\begin{array}{l}\text { Cawak \& } \\
\text { Kerjo }\end{array}$ & 30 & $\begin{array}{l}\text { Province road and village's roads were flooded. } \\
\text { Flooded area on } 2 \text { districts. }\end{array}$ & Kepuhbaru and Baureno \\
\hline
\end{tabular}


From that information, we can assesment based on the river, because the main river caused is overflow from river. There have some sub district where crossing by 2 river, and its make they became unsafe area. But, as well as knowing that people or community in those sub-district didn't want to leave their land or move out from there. It is gonna being problem for government and agency whose handle the problem of hazzard and disaster.

Living with the impendence disaster, made people more creative and know as well the early warning system and doing in tune with mitigation procudure. To improve the mitigation procedure, assesment of infrastructure needed and creating evacuated route. The evacuated route can be update during or after disaster, bacause damage of infrastucture unpredictable. From the information on table 6 , the route should avoid the river, cause road or bridges cross river is unsafe. Commonly the evacuted route and evacuated place consist of community from same village, purposed to facilitate data collection by headman. Map of flood area on bojonegoro imagery in figure 2 . from the maps showed that not all flooded area have evacuate place or route. Its indicated that all mitigation happened in additional. There some flooded area not have evacuate place, even though they have annual flooding too. From the village have some meet point. It is will facilitate communal and in order one policy and in the evacuate places and the process of rescue easier.

In these case, the route is a village roads and dont have anny choice like, which the biggest or shortest roads. From this assesment capable to inform to not take a path across river, stay away from river and the avoid flooded area.besaide that, it make an option to people for stay living in their village or moving. This option is a big deal with hazard and goverment.

\section{Evacuated Routed and Submerged Area in Bojonegoro}

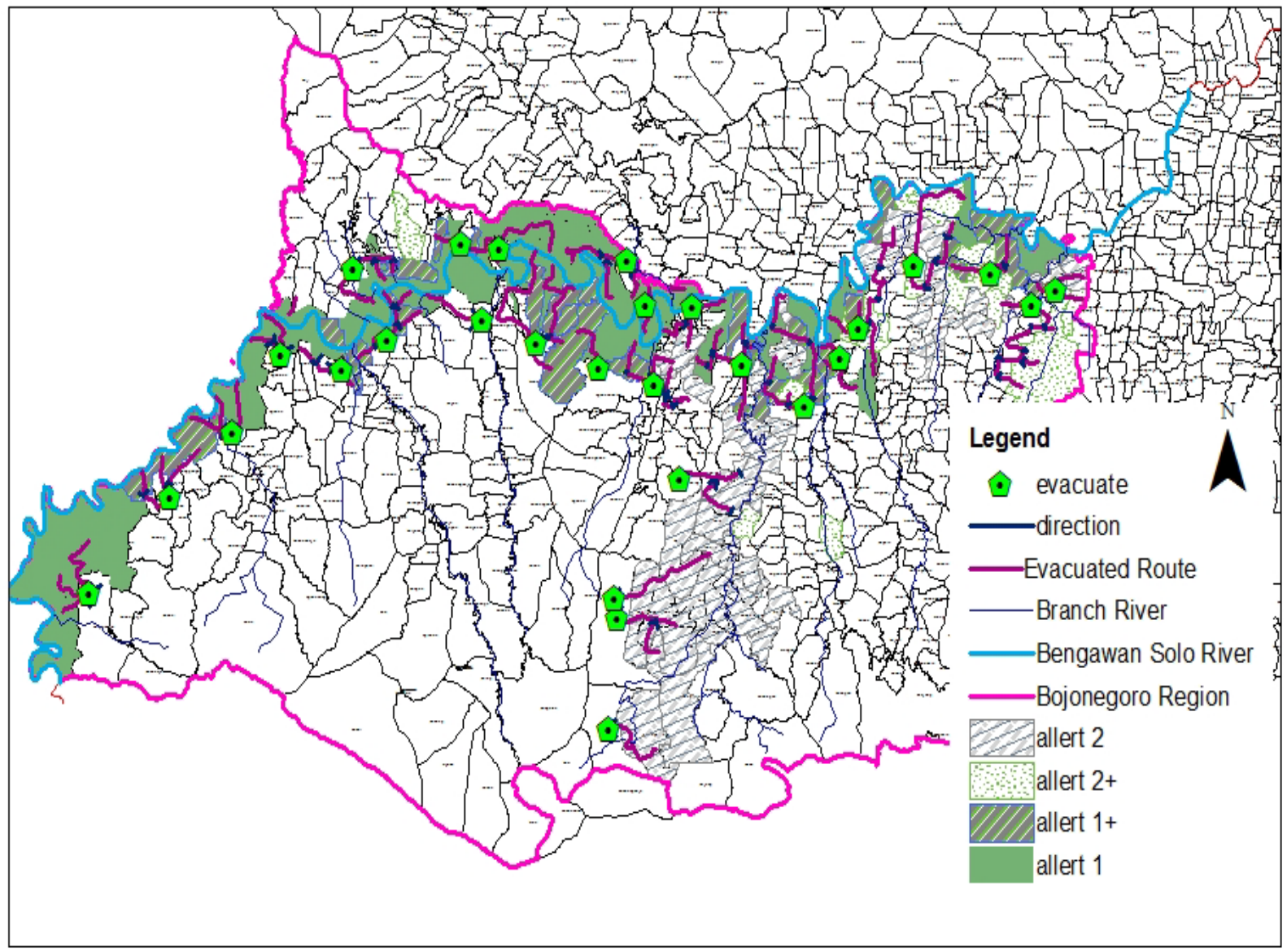

The map above described an alert area from 1 until 2+, when alert 1 is the first overflow happened. The villages got this area alert will continues until second alert or until 2+ alert. The first alert the area submerged around $50 \mathrm{~cm}$ level water from ground, and for 2+ it will reach until $250 \mathrm{~cm}$. the water level upgrade by the time and by the rain drop. The level water not be obtained estimated. In other hands the warning system could be produces by rainy season on November.and avoid the roads in alert area and use the route had been drawing in the picture.

On figure bellow imagery detail of the route. Like avoid river, take a look local roads for simplify the process evacuate, and shown that some evacuated place have been held in threatened flood area. the pictures had separated by area, to purpose give big screen area detailed. 


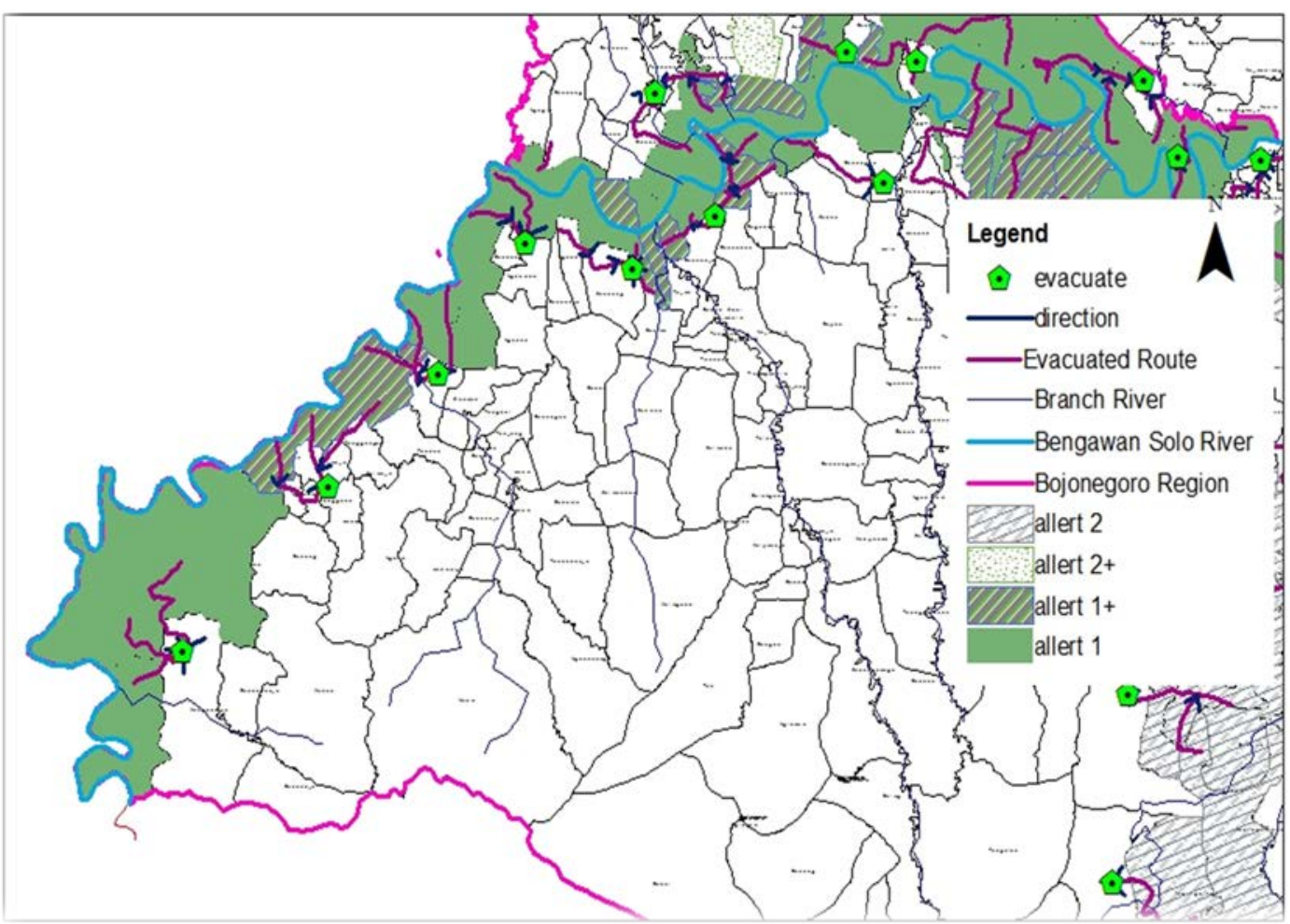

Figure 10. Evacuated Route and Submerged Area In Bojo negoro 1, Sub district Ngraho And Margomulyo

\section{Evacuated Routed and Submerged Area in Bojonegoro 2}

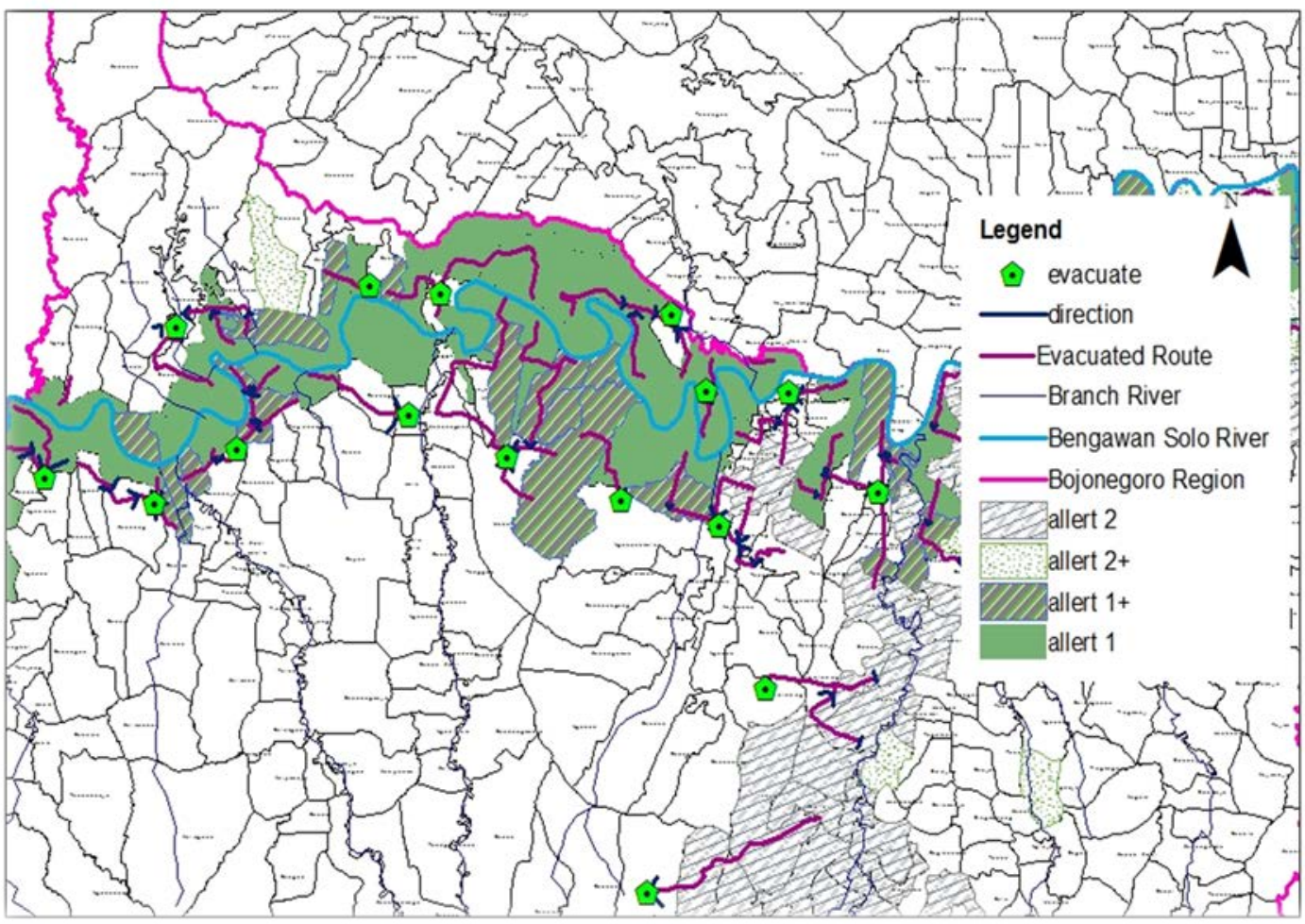

Figure 11. Evacuated Route and Submerged Area In Bojonegoro 2. Sub district Malo, Kasiman, Padangan, Bojonegoro, Kapas, Dender Sukosewu, Trucuk

Each picture showed the evaquated place with pentagonal shape, this place had coosen by emergency nasional agency. Completely with kitchen and ambulance. Some people ussualy just waiting until the rescue came because they did not know where the safety area. With this map, the civilitation can go through the area witahout waiting rescue team. 


\section{Evacuated Routed and Submerged Area in Bojonegoro 3}

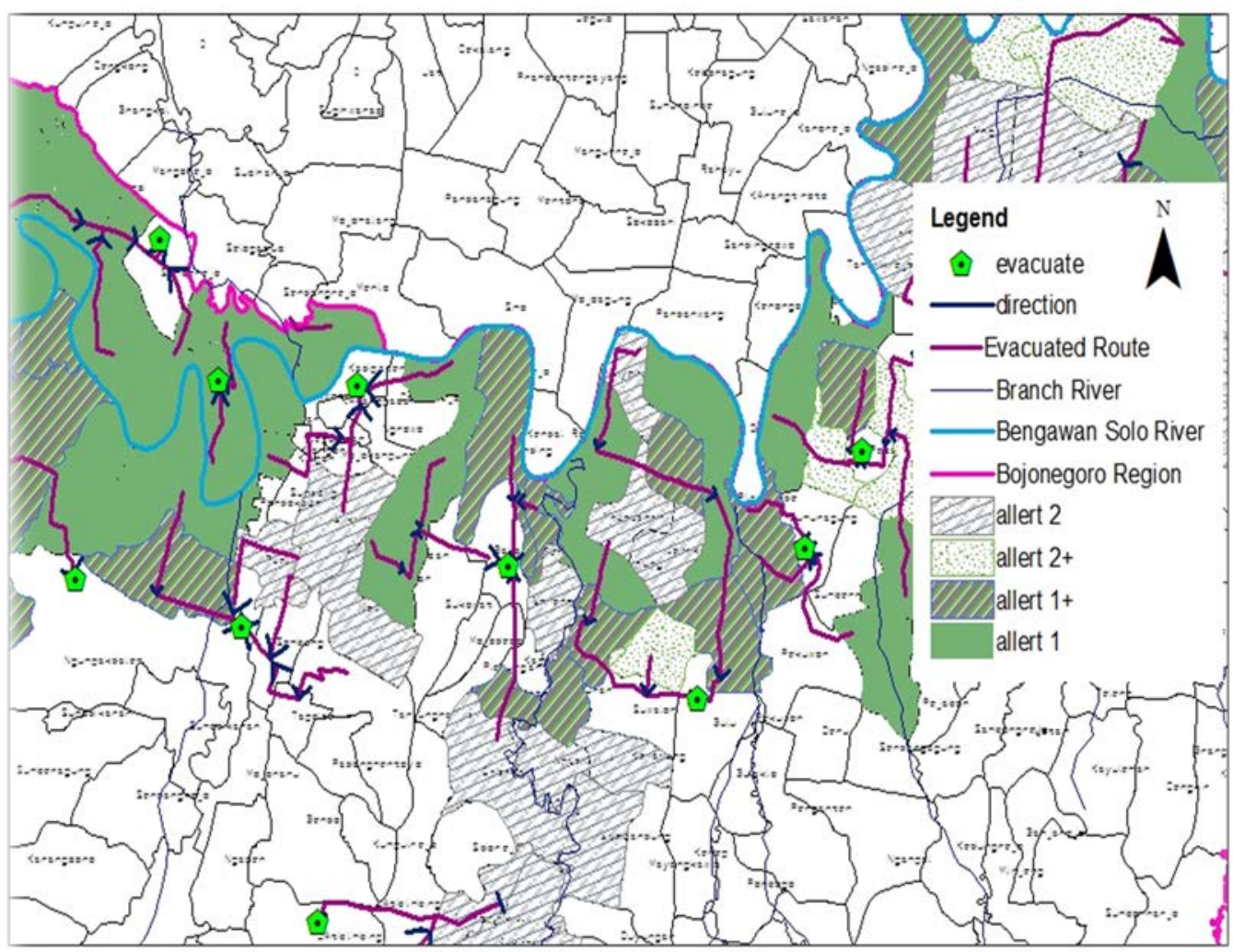

Figure 12. . Evacuated Route and Submerged Area In Bojonegoro 3 Sub district Bojonegoro, Kapas, Dender Sukosewu, Trucuk, Temayang

To create a map of disaster, need much information, not just what happened last year, but it was needed the histories of disaster event. Purpose to avoid the other risks.as well know floods will come every year, and in many times. Therefore need a completely information and awareness of community and the rescuer to safe their life.

\section{Evacuated Routed and Submerged Area in Bojonegoro 4}

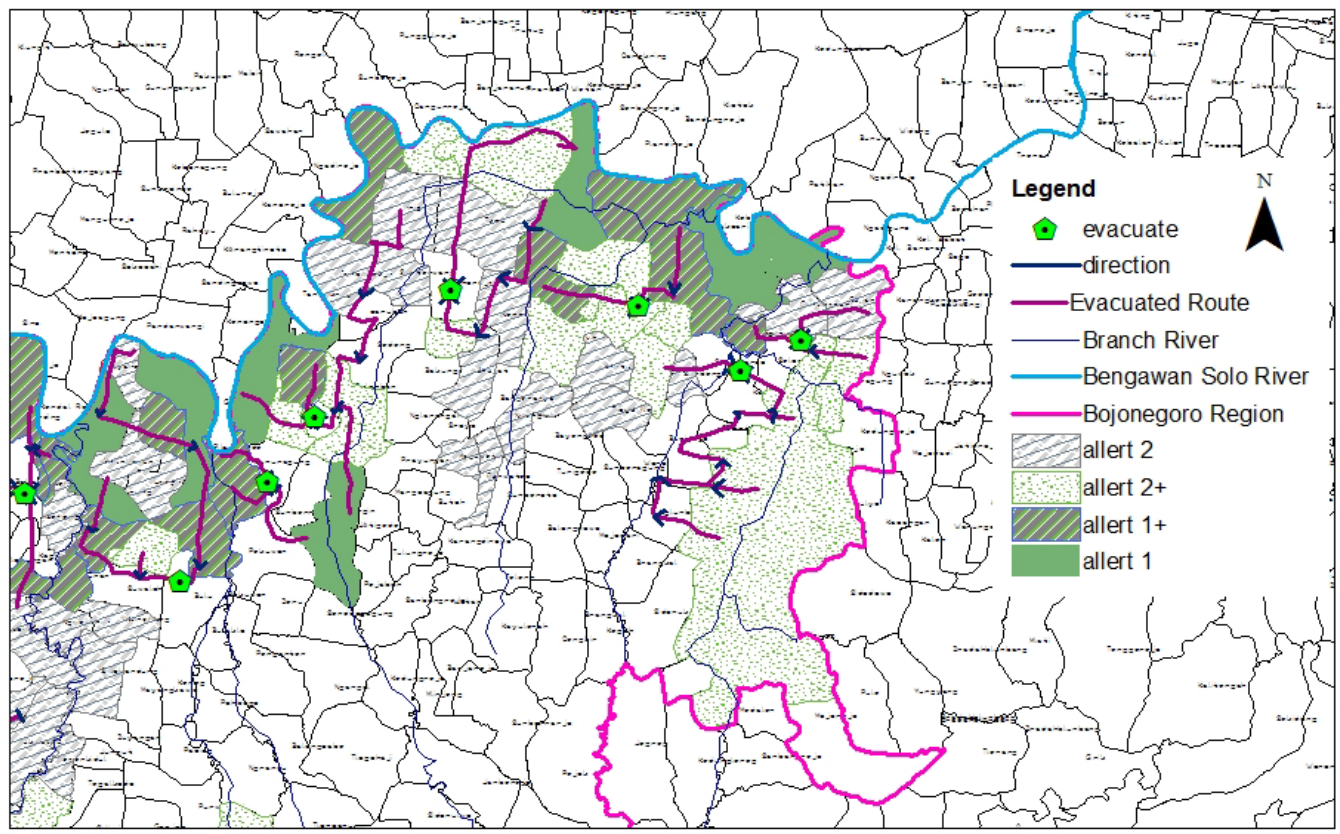

Figure 13 Evacuated Route and Submerged Area In Bojonegoro. Sub district Malo, Kasiman, Kapas, Dender Sukosewu, Trucuk 


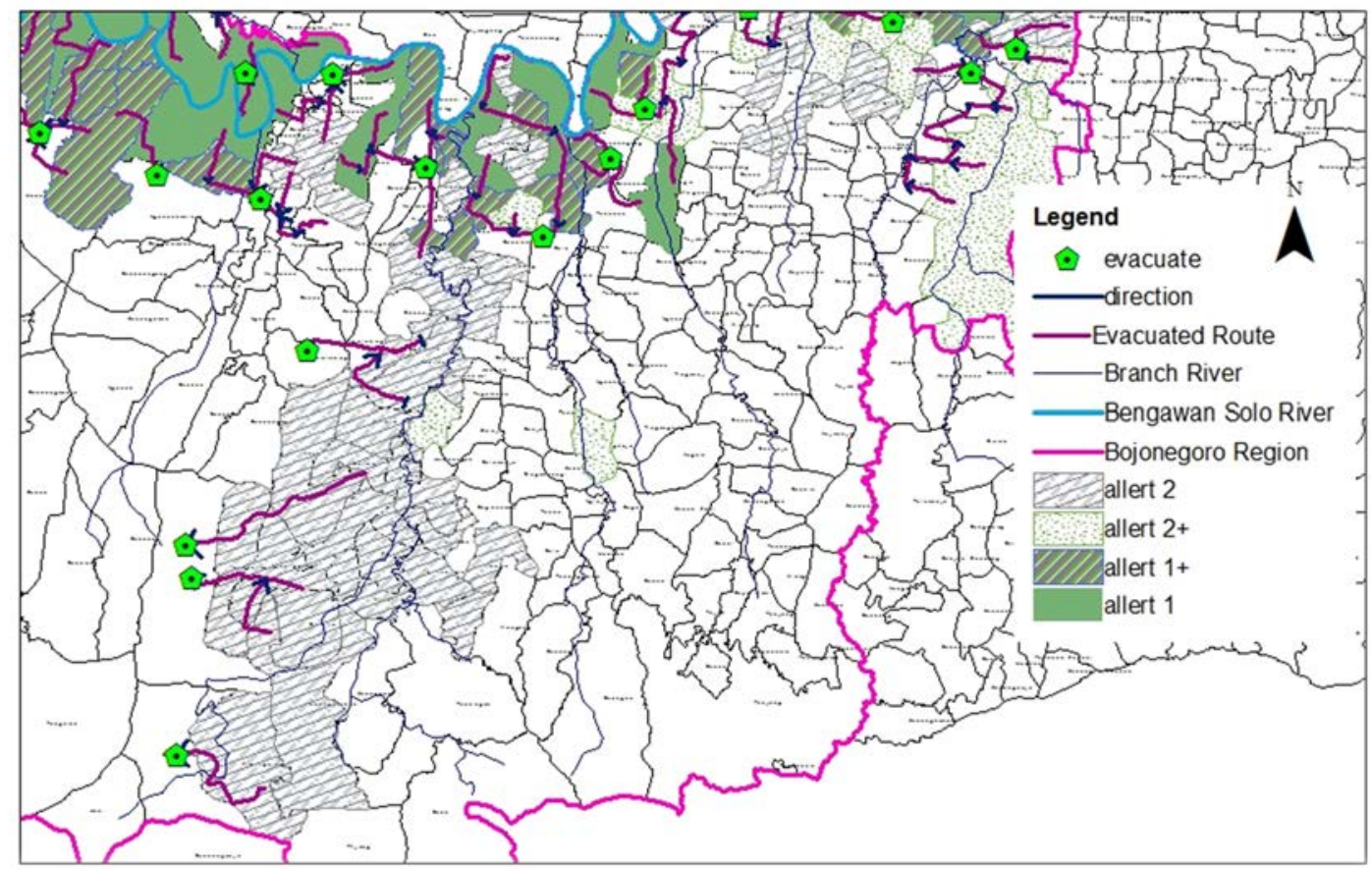

Figure 14. floded village area 5 and evacuated route 5. sub district Kanor,Baureno, Kepuhbaru, Sumberejo

Based on those figure ( fig 4 until fig. 7), colored area representative the flooded area from the high flooded water level. The red color showed flooded area 1 with flooded level from 150- $250 \mathrm{~cm}$, and these areas were the first floods came. Then flooded area 2 had level flooded high 100-150. All area were the risk flooded area with different level flooded high, it may causing of the area have low topography are in 11sea level until 25 sea level. With the result that, community of those village should be aware in rainy season and prepare for evacuated if it necessary. The evacuated route information detail of village inform on table 7 bellow.

Table 6. Evacuated Route Information Detail by Village

\begin{tabular}{|c|c|c|}
\hline No. & Evacuated & From village \\
\hline 1. & Margomulyo & Ngalo, kalangan, luwih haji \\
\hline 2. & jumuk & Mojorejo, ngraho, blimbinggede, tapelan, sumberarum, tanggungan , kalirejo \\
\hline 3. & Banker & Payaman, teban, prangi, purworejo \\
\hline 4. & Ngasiman & Dengak, padangan, ngulanan, sidorejo, cepada, kuncen \\
\hline 5. & Kendung & Kebunagung, banjarejo, naradin, purwosari \\
\hline 6. & Tambak merak & $\begin{array}{l}\text { Sumberejo, tambakmerak, batokan, betet, tembeling, dukuh, sidomukti, kalangan, } \\
\text { manukan, petak, tambakromo, sumberejo, besaki, betet }\end{array}$ \\
\hline 7. & Brawokan & Banjarejo, bagel, ngraho, manukan, sudu, ringin tunggal, bagelan, cengklungan. \\
\hline 8. & Tangir & Sukerejo, malo, trembesi, kanten, smelaran, tulungagung. \\
\hline 9. & Wadang & $\begin{array}{l}\text { Pilangsari, mojosari, brenggola, kaltidu, pajunan, mayanggareng, mayangrejo, pajunan, } \\
\text { plungplungan }\end{array}$ \\
\hline 10 & Ngumpak dalem 1 & Leren, sukoharjo, ngulanan \\
\hline 11 & Ngumpak dalem 2 & Sumbertlaseh, jetak, pandaksari, pacul, sembung, tapelan \\
\hline 12 & Sumberejo & Trucuk, sumbangtimun, kandengan, pagerwesi, padang, trucuk \\
\hline 13 & Trucuk & Goyangan, sranak, tulungrejo \\
\hline 14 & Kadipaten & Karang pacar, campurejo, mulyoagung, kapatihan, mojokampung, sukorejo, klagan \\
\hline 15 & Bakulan & Sambiroto, ngampel, tikusan, kalianyar, sukowati, semlandingan \\
\hline 16 & Bulu & $\begin{array}{l}\text { Sewaloh, kabunan, mulyoagung, mulyoagung, sekaran, kedungdowo, lengkong, } \\
\text { margomulyo, prambanan, balenrejo }\end{array}$ \\
\hline 17 & Sumuragung & Pilanggede, sarangan, pakuwon, kedungbondo \\
\hline 18 & Pesen & $\begin{array}{l}\text { Simbatan, cangaan, glagahsari, tejo, kanor, prigi, tambahrejo, carupan, sedeng, piyak, } \\
\text { patembanan, talun, begangin }\end{array}$ \\
\hline 19 & Simorejo & Bugangan, temu, pomahan, pucangarum, sedangarum, kedungprimpen, sembunglor. \\
\hline 20 & Pasiman & Karang dayu, kauman \\
\hline 21 & Sugih waras & Blangsungan, sumurgede, karangan, betet, bumirejo, muju, jetak, krangsang \\
\hline 22 & Selorejo & Tulungagung, gunungsari, gajah, sumur agung \\
\hline
\end{tabular}




\section{Conclusion}

The research had many summaries to produces the new alarm system and to build evacuated map for community in flooded area. The summaries such as :

a) The factors of Bengawan solo floods are, overflow from member of group this river, and the topography of Bojonegoro. Rainy season in this district start from November, in case the people must be warned when this season.

b) The assessment of infrastructure gave 349 point from 400, this indicate infrastructure get high

\section{References}

[1] Adelman. Deborah S, Disaster Nursing: A Handbook For Practice, Jones \& Bartlett Learning; 1st edition, October 23, 2008

[2] Badan Nasional Penanggulangan Penanggulangan Bencana (BNPB) , Peraturan Kepala BNPB nomor 02 tahun 2012, tentang Pedoman Umum Pengkajian Risiko Bencana, Republik Indonesia, 2012

[3] Direktorat Pengairan dan Irigasi (2014), Kebijakan Penanggulangan Banjir di Indonesia, Deputi Bidang Sarana dan Prasarana Direktorat Pengairan dan Irigasi, Indonesia, 2014

[4] Febrianti, Fety ,Flood Risk Perception and Copping Mechanism of Local community : a case study in part Surakarta city, Central Java Province Indonesia, Thesis Master, ITC Faculty University Of Twente, Twente, 2010.

[5] Indonesia, Forest Watch, Modul pelatihan sistem informasi geografis 31 Januari - 15 Februari tahun 2010, Forest Watch Indonesia, Bogor, 2010

[6] Indradewa, Meilani Safira. Potensi dan upaya penanggulangan bencana banjir sungai wolowona, nangaba dan kaliputih di Kabupaten Ende, postgraduate program , Universitas Sebelas Maret Surakarta, Surakarta, 2008

[7] BPBD east java, contingensi report, BPBD Report, 2014 effect in this area. The Condition infrastructure for advantage evacuation route while the flood suggested to avoid the river, it is unsafe track. Then almost the rail road must be moved to higher elevated.

c) From the information capable to mapping the flooded area and evacuation route in Bojonegoro District. Even got information that not all area have evacuated place.

[8] Oscar Amarasinghe. "Building Resilience: Fisheries Cooperatives in Southern Sri Lanka", Poverty Mosaics Realities and Prospects in Small-Scale Fisheries, 2011.

[9] Water resource departemen of PU, Pengairan Dalam Angka 2008-2009, Water resource on demand the series, 2009.

[10] Water resourche departemen of PU, Pengairan Dalam Angka 2010-2011, Water resource on demand the series, 2011.

[11] Water resourche departemen of PU, Pengairan Dalam Angka 2011-2012, Water resource on demand the series, 2012

[12] Water resourche departemen of PU, Pengairan Dalam Angka 2012-2013, Water resource on demand the series, 2013

[13] Water resourche departemen of PU, Pengairan Dalam Angka 2013-2014, Water resource on demand the series, 2014.

[14] Wisner, ben and friends, at risk natural hazards, people's vulnerability and disaster second edition, routledge, 2004.

[15] UNDP, Bureau for Crisis Prevention and Recovery “ Disaster Risk Assessment”. One United Nations Plaza New York NY 10017 USA, www.undp.org, October, 2010.

[16] PU department, Mitigation and hazzard policy, 2012 